\title{
STUDENT EXPECTATIONS TOWARDS PHYSICAL ENVIRONMENT IN HIGHER EDUCATION
}

\author{
Lasma Licite, Lana Janmere \\ Latvia University of Life Sciences and Technologies, Latvia \\ lasma.licite@1lu.lv, lana.janmere@1lu.lv
}

\begin{abstract}
Investment in higher education is an essential prerequisite for economic growth and national competitiveness as well as for achieving a higher level of prosperity. To implement it, an important role is played by various affecting factors, including the quality of the physical environment of an educational institution that affects the learning process, determines physical and mental self-feeling and motivation and contributes to emotional and behavioural responses. In view of the fact that the millennial generation, whose values differ from those of previous generations, enters universities, the research aim is to examine students' expectations towards the physical environment in higher education institutions. The research was carried out at the Latvia University of Life Sciences and Technologies that is a classical university of biotechnology and technology with 155 years of tradition. The research analysed the physical environment through three aspects: the layout and size of study rooms, ergonomics and technologies, and the informal environment and comfort. A survey of young students revealed that in describing an ideal study room, students demonstrated the values typical of the millennial generation - they stressed the roles of technologies and comfort. However, if the role of the teaching personnel is contrasted with the availability of technologies in the physical environment for studies, the technologies lose their value. The student opinions on the physical environment for studies showed homogeneity, yet the ratings of some aspects represented statistically significant differences between the social science students and the students studying other sciences.
\end{abstract}

Keywords: millennials, physical environment, higher education.

\section{Introduction}

The Education Development Guidelines for 2014-2020 prescribe that education is important for every individual, the family, society and the country as a whole. This is a way towards the quality of individual lives, a knowledge society, economic growth and prosperity. Besides, investment in higher education is an essential prerequisite for economic growth and national competitiveness as well as for achieving a higher level of prosperity [1]. To implement it, an important role is played by various affecting factors, including the quality of the physical environment of an educational institution.

For a number of years, various research studies [2-3] reveal that student achievements do not depend only on the curricula, teaching techniques and social relations, but also on the physical environment of an educational institution, as the environment of a higher education institution in its various levels has an impact on the course of personality socialisation and culturalization as well as on its intensity [4]. The physical asset and facilities environment give educational institutions their appropriate shape and atmosphere for teaching and learning [5] and is one of the factors that provide quality [6]. Besides, a number of research investigations into constructivism [7-8] stress that the physical environment for studies plays an essential role in the learning process as well as determines physical and mental self-feeling, contributes to motivation and various emotional and behavioural responses [9] and impacts on students' wellbeing [10]; therefore, it is important to examine what the physical environment, in which it is possible to effectively process information, actively build up one's knowledge, competences and ability to study independently, has to look like.

Since the beginning of the $20^{\text {th }}$ century, a number of important research studies have been done in pedagogy and social psychology on the impacts of the environment on an individual's behaviour, cooperation between the schoolchild and the teacher, satisfaction with the environment and other essential aspects [11]. However, research on the physical environment for learning in Latvia mainly focuses on the environment for learning at school as a place for socialisation and experience build-up [4], as a social and pedagogical system [12-13], as working environment for schoolchildren and teachers [14] and a characteriser of the school's culture [15-16]. However, it is urgent to research the physical environment at higher education institutions and its role in the learning process, as the generation that enters universities in recent years considerably differs from the previous generations.

The vast majority of first-year undergraduate students are called millennials, they have different learning habits compared with their predecessors [17] and different expectations towards the physical 
environment. Millennials are the generation born after 1982, in a period, when the digital technology and the Internet developed. However, the millennial generation emerged in Latvia only in the early 1990s, i.e. after the collapse of the Soviet Union, because the characteristics and division of generations make major influences in the environment, within which early human socialisation occurs [18].

Millennials expect technologies in classrooms [19], more society integrated learning environment [20-21] and they are no longer fixed on one place for their studies [22]. The learning environment is not only a classroom anymore, learning can happen anywhere, because students are learning in diverse environments. Every place can become a learning atmosphere, where knowledge can be discovered [19].

The research aim is to examine students' expectations towards the physical environment in higher education institutions. To achieve the aim, the following specific research tasks are set: 1) to examine the theoretical aspects of a physical environment; 2) to characterise students' expectations towards the physical environment in Latvia, by counteracting millennial and generation $\mathrm{X}$ values.

\section{Materials and methods}

The research was based on a questionnaire survey, in which millennial students were asked about their expectations towards the physical environment. The survey was made at the Latvia University of Life Sciences and Technologies, which is one of the largest universities in Latvia that prepares professionals in biosciences, engineering and social sciences. The questionnaires were handed out to 365 first- and second-year students of different study programmes. Students were in the age from 18 to 21 years. The survey period was January, 2017.

The students' expectations were measured on a semantic differential scale of nine categories, and each of the expectation indicators was expressed as a pair of two opposite assertions. In every pair of assertions, one of the assertions reflected the opinion of the millennial generation about the university, while the other showed the values of generation X. Values of different generations are extracted from social researches about youth and adults, and their life preferences [18]. In this way, examining every pair of assertions allowed identifying the values of a generation, which the students associated themselves with. Choosing a category from 1 to 3 meant that the students preferred the values of the millennial generation, while the choice of a category from 5 to 7 indicated an opinion of someone from Generation X. However, the choice of a category numbered 4 indicated a neutral opinion, showing no concrete value preference. Central trend and dispersion indicators, i.e. the arithmetic mean (M) and standard deviation (SD) were employed in processing and analysing the survey data [18]. The questionnaire was originally made for this survey, and physical environment as construct was measured on a small scale sample size using only 9 items (Cronbach's-Alfa coefficient varies among 0.59-0.63), therefore, assertions have acceptable internal consistency. Non-parametric tests (MannWhitney test) were employed to analyse differences in the opinion of bioscience, engineering and social science students, as according to the Kolmogorov-Smirnov test results the data acquired did not match a normal distribution.

\section{Results and discussion}

Theoretical aspects of a physical environment. The concept of environment is interdisciplinary, as it is researched by natural, social, humanitarian and engineering sciences [11]. In a broader sense, it represents everything that surrounds us, most often it is understood as a set of certain circumstances and impacts [4]. R. Burceva distinguishes the following environmental contexts that continuously interact with one another: physical, social, psychological, informative and pedagogical. The identified environmental contexts for education are not subordinated to one another, yet they are interdependent and pliable, and symbiotic attitudes exist among them. The mutual interaction of the components occurs nonlinearly and in several directions simultaneously, while maintaining some balance [4].

Analysing the physical environment in particular, researchers focus on the most essential criteria for it: rooms of an educational institution and the surrounding environment [23], functionality (size, layout and furniture of the room etc.), ergonomics (lighting, temperature, ventilation, sounds etc.) and the aesthetic of the physical environment [24]. Technical equipment and the availability of work and resting rooms are stressed in particular [9]. The physical environment in higher education involves the 
provision of buildings, classrooms, hostels, staff quarters, workshops, laboratories, ICT centres, libraries, health centres and sports facilities [5]. The physical environment is analysed in three aspects: the layout and size of study rooms, ergonomics and technologies, the informal environment and comfort.

As pointed out in various research investigations into the environment [11], it is not possible to employ or design a single ideal model for the environment for studies, as the youth establish relationships differently and adapt to requirements. Studying does not take place in some neutral room, but in a specific temporal, spatial, social, cultural and economic environment; consequently, student teaching experience might be different within one study course. Individuals could perceive one and the same room differently. Besides, the environment for studies for millennial students is not only their university, but also other human-made environmental objects, e.g. a library, the home, an enterprise etc. as well as the virtual environment [11]. Millennial students expect that study rooms are open in a 24/7 mode (all days per week and without time restrictions), they have fast access to resources (library) or support [19]. Research studies indicate that nowadays, education environments have two forms - traditional and virtual education environments [25].

Upon beginning their studies, the youth choose their environments themselves, which determine their abilities and possibilities to analyse and assess diverse and changing processes, develop independent research skills and build up professional competences in future, thereby turning into personalities [4]. However, the expectations often do not match the reality; consequently, the studies are discontinued because of various factors, including dissatisfaction with the physical environment. Even though a lot of efforts have been made to enhance infrastructures at universities in Latvia in recent years by using EU funding, thereby making the physical environment better equipped, structured and modern, and the process of studies is entered by various technologies [26], the available funding is not sufficient. The Education Development Guidelines for 2014-2020 state that it is necessary to raise the quality of studies through enhancing curricula and infrastructure [1].

Millennial student expectations towards the physical environment at university. The ratings of the physical environment by students show inclination towards the values of the millennial generation, preferring the ergonomics, comfort and technological opportunities of the physical environment, if choosing between two alternatives. Such expectations towards the physical environment are observed for most of the criteria related to an ideal study room (Fig. 1).

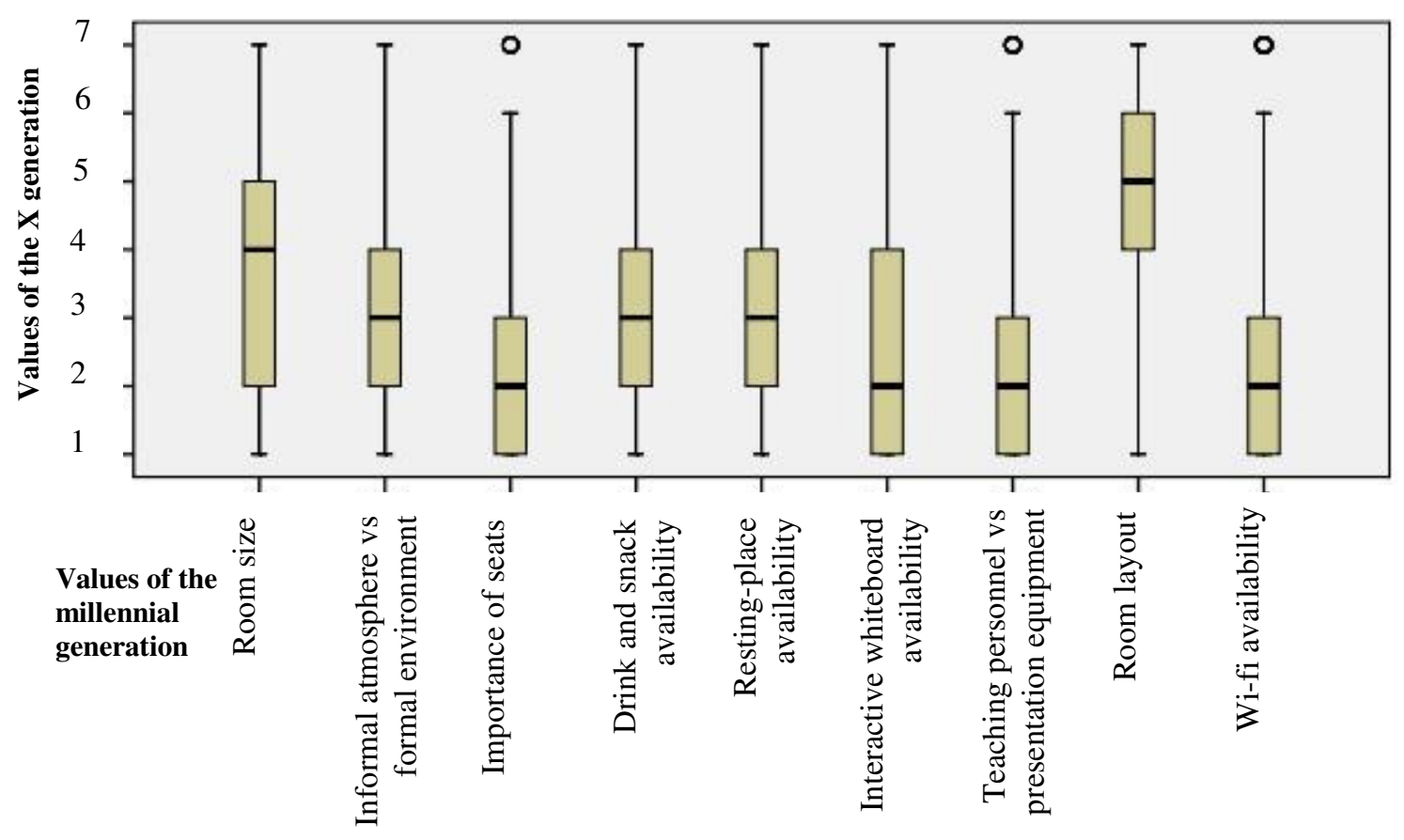

Fig.1. Average ratings of physical environment for studies and dispersion of ratings: a scale of

1-7 shows inclination towards the values of the millennial generation, where 1 is the strongest inclination, while 7 is the weakest inclination 
Ergonomics and technologies. The highest agreement among the students was observed for seats and their ergonomics: comfortable and soft seats were preferred more often than the alternative "seats play no important role"; therefore, the average rating of the criterion "importance of the seat" was 2.14 (SD 1.52). However, there were statistically significant differences between the social science students and the students studying other sciences $(p<0.05)$, as they stressed the importance of the seat more frequently than the others. Overall, if choosing between two alternatives, only $9 \%$ of the surveyed youth revealed that seats in their ideal study room were not important, while $6 \%$ gave a neutral rating to this criterion and did not specify whether it was important to them.

However, along with the importance of a seat, the technologies and layout of a study room were also important. As regards the criterion "wi-fi availability", most of the surveyed youth $(77 \%)$ preferred the alternative "wi-fi is available and used during classes" with different levels of agreement; the average rating was 2.37 (SD 1.63). The criterion "interactive whiteboard availability", rated by the students, had fewer extreme ratings than the criteria regarding seats and wi-fi had, yet overall, $63 \%$ preferred an interactive whiteboard rather than a flipchart. In the result, the average rating of this criterion was 2.73 (SD 1.52). Besides, a relatively large number of the surveyed youth (28\%) did not give a particular rating.

If contrasted with the role of the teaching personnel, the role of technologies in the physical environment for studies was not rated highly by the youth. It is interesting that in case the youth had to choose between an inspiring speech and presentation equipment (a projector, a screen), $79 \%$, with different levels of agreement, would prefer an inspiring speech in their ideal study room. This means that the social aspect is very important for the millennial generation; furthermore, in case of choice, it plays a more essential role that technologies do. The criterion "teaching personnel vs presentation equipment" was rated, on average, at 2.27 (SD 1.57), which indicated overwhelming prevalence of the teaching personnel over the latter. Besides, the ratings of this criterion, just like those of importance of seats and wi-fi availability, showed that the youth demonstrated the highest inclination towards the values of the millennial generation.

Layout and size of rooms. The ratings of the layout of an ideal study room showed that the youth opinions differed, and the ratings were lower for the assertions that reflected the values of the millennial generation. Explicitly more traditional expectations related to the layout of a study room. A classical auditorium with a rostrum for a university lecturer as an ideal solution was chosen by $52 \%$ of the surveyed youth, thereby preferring the traditional layout of the study room, while an auditorium laid out as a round table for discussion promoting the interaction of the youth involved in the learning process was favoured by $21 \%$. The average rating of the criterion "layout of a study room" was 4.67 (SD 1.76), which was the highest for all the criteria of the physical environment for studies, reflecting the heterogeneity of values of the surveyed youth. There were statistically significant differences among the students of all the three sciences $(\mathrm{p}<0.05)$, yet the social science students (with an average rating of 5.20) and the engineering students ( $\mathrm{M} 4.81$ ) preferred the traditional layout of a study room.

It is also indicated by the differences in the opinion on the size of an ideal study room, as $40 \%$ would prefer studying in a small room for seminars, while $36 \%$ would wish a large auditorium for lectures. The average rating of the criterion "auditorium size" was 3.93 (SD 1.69), which overall indicated unconvincing agreement on the values of the millennial generation. Most often, the social science students (M 5.10) and the bioscience students (M 3.99) would prefer studying in a large auditorium for lectures, thereby reflecting the highest preference for the values of generation $\mathrm{X}$. It could be considered a statistically significant difference between the student groups $(\mathrm{p}<0.05)$.

Informal environment and comfort. As regards the criterion ,informal atmosphere vs formal environment", the youth mainly prefer the informal environment; however, they mainly associated the layout of a study room with a classical, formal auditorium. An informal atmosphere rather than a formal environment was preferred by $58 \%$ of the surveyed youth. The average rating of this criterion was 3.33 (SD 1.65), and it mainly reflected the expectations of the millennial generation, although the dispersion of the opinions was relatively high.

Similarly to an informal atmosphere, the youth rated additional comforts in a study room - a place for a rest and the availability of drinks/snacks. The opinions on the need for them were different and 
dispersed. Nevertheless, the average ratings showed inclination towards the values of the millennial generation, i.e. the need for such comforts. Of the surveyed youth, $24 \%$ wished to see equipment needed only for studies in study rooms, while $18 \%$ did not give any rating. Overall, the average rating of the criterion "resting-place availability" was 3.39 (SD 1.8), while the criterion "drink/snack availability" was rated, on average, at 3.28 (SD 1.89). Besides, there were statistically significant differences in the ratings of drink/snack availability among the student groups $(p<0.05)$ and in the ratings of resting-place availability between the engineering and the social science students $(p<0.05)$. Overall, the students preferred additional comforts in their ideal study room and did not favour the approach that only equipment needed for studies has to be present in the study room.

\section{Conclusions}

1. The quality of the physical environment of an educational institution is very important for provision of effective study process. According to scientific researches it affects the learning process, determines physical and mental self-feeling and motivation, and contributes to emotional and behavioural responses. However, individuals could perceive one and the same room differently; besides, for millennial students, the environment for studies is not only the university, but also any other human-made environmental objects, e.g. a library, the home, an enterprise etc. as well as the virtual environment.

2. In the study, 365 first- and second-year bioscience, engineering and social science students of the Latvia University of Life Sciences and Technologies rated three aspects of the physical environment: the layout and size of study rooms, ergonomics and technologies, and the informal environment and comfort. The students' expectations were measured on a semantic differential scale of seven categories.

3. In describing an ideal study room, students demonstrated the values typical of the millennial generation - the important roles of technologies and comfort. However, if the role of a university lecturer is contrasted with the availability of technologies in the physical environment for studies, the technologies lose their value.

4. The student opinions on the physical environment for studies showed homogeneity, yet the ratings of some aspects represented the specifics of social sciences and statistically significant differences between the social science students and the students studying other sciences. The social science students preferred a classically equipped physical environment with large, amphitheatre-type auditoriums, yet, they stressed the need for additional comforts and ergonomics of seats.

5. It is important to continue modernisation of the environment for studies at higher education institutions, given the expectations of millennial students and the increasing role of the ICT in the learning process.

\section{References}

[1] Izglìtības attīstības pamatnostādnes 2014. - 2020. gadam (The Education Development Guidelines for 2014-2020), Rīga, 2013. 148 p. (In Latvian).

[2] Anderson L., Ryan D.W. The IEA classroom environment study. New York: Oxford University Press, 1973. $272 \mathrm{p}$.

[3] Earthman G. The quality of school buildings, student achievement and student behavior. Bildung und Erziehung, vol. 52, 1999, pp. 353-372.

[4] Burceva R. Environment of education in higher education institutions. Proceedings of scientific articles: Izglītîbas iestāžu mācību vide: problēmas un risinājumi, 2006, pp.87-93.

[5] Musa M.F., Ahmad Z. Higher education physical assets and facilities. Procedia - Social and Behavioral Sciences, vol. 50, 2012, pp. 472-478.

[6] Šolc M., Markulik Š., Sutoova A. Quality in contemporary University environment. Procedia Social and Behavioral Sciences, vol. 143, 2014, pp. 703-707.

[7] Fraser B.J. Classroom education environments. In: Handbook of research on science education. New Jersey, 2007, pp. 103-124.

[8] Žogla I. Didaktikas teorētiskie pamati (Theoretical Basics of Didactics). Riga: Raka, 2001. 275 p. (In Latvian). 
[9] Laizāne A. The evaluation of fluctuation and diversity of the educational environment of rural schools in Latvia. Summary of Doctoral Thesis. Jelgava: LLU, 2012. 41 p.

[10] Castilla N., Llinares C., Bravo J.M. etc. Subjective assessment of university classroom environment. Building and Environment, vol. 122, September, 2017, pp. 72-81.

[11]Šūmane I. Pusaudžu mācību sasniegumus veicinoša mācību vide (Teaching Environment Conducive to Teenage Learning Achievements). Doctoral Thesis. Riga: LU, 2012. 180 lpp. (In Latvian).

[12] Katane I. Lauku skola kā izglītîbas vides izvērtēšanas modelis (Rural School as a Model for Assessment of the Educational Environment). Summary of Doctoral Thesis. Daugavpils: Daugavpils Universitāte, 2005. 35 p. (In Latvian).

[13] Pēks L. Pedagoğiskā vide un tās sociālpsiholog̣iskais komponents (Pedagogical Environment and its Socio-psychological Component). Sabiedrība un kultūra, 1999, pp. 98-107. (In Latvian).

[14] Bērziṇa A., Gedrovics J. Skolas darba vide kā nozīmīgs faktors bērniem draudzīgas skolas izveidošanai (School Working Environment as an Important Factor for The Formation of a Children-friendly School). Scientific articles: Izglītības ekoloǵija un profesionālās studijas, Rīga: RUK \& RPIVA, 2007, pp. 61-69. (In Latvian).

[15] Katane I. Skola kultūrā un kultūra skolā (School Culture and Culture at School). Jelgava: LLU, 2006. 135 p. (In Latvian).

[16] Lūsēna-Ezera I. Komandas darba principu pielietojums Latvijas vispārizglītojošo izglītības iestāžu vadīšanā (Application of Teamwork Principles to the Management of General Education Institutions in Latvia). Doctoral Thesis. Riga: LU, 2010. 176 p. (In Latvian).

[17] Carrasco-Gallego J.A. Introducing economics to millennials. International Review of Economics Education, vol. 26, September, 2017, pp. 19-29.

[18]Licite L., Janmere L. Millennial student expectations towards higher education in Latvia. Proceedings of International scientific conference "Engineering for rural development", May 24 26, 2017, Jelgava, Latvia, vol. 16, pp. 1440-1445.

[19] Kahl C. Students' dream of a "perfect" learning environment in private higher education in Malaysia: An exploratory study on "education in private university in Malaysia". Procedia Social and Behavioral Sciences, vol. 123, 2014, pp. 325-332.

[20]Bracy C., Bevill S., Roach T.D. The millennial generation: Recommendations for overcoming. Proceedings of the Academy of Educational Leadership, vol. 15, issue 2, 2010, pp. 21-26.

[21] Jung J.Y., Lin W.Y., Kim Y.C. The dynamic relationship between East Asian adolescents' use of the internet and their use of other media. New Media \& Society, vol. 14, issue 6, 2012, pp. 969-986.

[22] Martin C.A. Getting high on Gen Y: How to engage the entitlement generation. Career Planning and Adult Development Journal, 2008, pp.19-23.

[23] Orska R. Social environment's influence to pupil's behaviour. Proceedings of scientific articles: Izglītības iestāžu mācību vide: problēmas un risinājumi, 2006, pp. 7-18.

[24] Gudro I., Lejniece Z., Freivalde L. Mācību iestādes interjera nozīme mūsdienu komunikācijā (Role of the Interior of an Educational institution in Modern Communication). Proceedings of Riga Technical University scientific article: Materiālzinātne. Tekstila un apǵērbu tehnoloǵija. No. 5, 2010, pp. 41-46. (In Latvian).

[25] Sevindik T., Demirkeser N., Comert Z. Virtual education environments and web mining. Procedia Social and Behavioral Sciences, vol. 2, 2010, pp. 5120-5124.

[26] Izglītīibas darbinieku vajadzības nodarbinātības stabilitātes un cien̄̄ga darba apstākḷu nodrošināšanai un šo jautājumu aktualizēšanai kolektīvajos līgumos (Needs of Pedagogical Employees for Ensuring Stability and Decent Work Conditions and Raising Issues in Collective Agreements), LLU, 2013. 128 p. (In Latvian). 